\title{
Colony integration in honey bees: genetic, endocrine and social control of division of labor
}

\author{
Gene E. Robinson*, Zhi-Yong Huang \\ Department of Entomology, University of Illinois, Urbana, IL 61801, USA
}

(Received 5 July 1997; accepted 12 November 1997)

\begin{abstract}
This paper reviews our understanding of the mechanisms that enable adult worker honey bees to show plasticity in age polyethism in response to changing environmental conditions. There are genotypic differences in rate of behavioral development, which predispose individuals to respond to changing conditions in predictable ways. For example, genotypes that have relatively fast rates of behavioral development under more typical conditions are more inclined to show precocious foraging in the absence of foragers of normal age. Juvenile hormone influences rate of behavioral development, and environmentally induced changes in JH titers are thought to underlie changes in age polyethism. Results of recent experiments indicate that changes in the age at onset of foraging caused by changes in colony age demography are at least partially a consequence of social interactions in which older bees inhibit the rate of behavioral development of younger bees. Chemical signals are suspected to feature prominently in these interactions, and preliminary evidence supporting this notion is presented. (1nra/DIB/AGIB/Elsevier, Paris
\end{abstract}

Apis mellifera / behavioral genetics / juvenile hormone / chemical communication

\section{INTRODUCTION}

One central feature of many insect societies is an age-related division of labor among the workers, in which individuals perform different tasks at different ages [reviewed by Robinson (1992)]. Agerelated division of labor is based on a form of behavioral development by workers known as age polyethism. The basic pattern of age polyethism is strikingly similar from species to species (Hölldobler and Wilson, 1990). Young individuals perform tasks in the nest such as brood care and nest maintenance, and then venture outside to collect food and defend the nest when they get older.

\footnotetext{
* Correspondence and reprints

Tel.: (1) 217265 0309; fax: (1) 217244 3499; e-mail: generobi@uiuc.edu
} 
Worker honey bees (Apis mellifera) show typical age polyethism [reviewed by Winston (1987), Robinson (1992) and Moritz and Southwick (1992)]. They spend the first 2-3 weeks of adult life working in the hive and the remaining 1-3 weeks of life mostly as foragers. But honey bee age polyethism is not rigid; rather, bees are extremely sensitive to changes in their environment [reviewed by Robinson (1992)]. A flexible system of division of labor presumably is very important to colony fitness because a bee colony must develop and produce reproductives despite constant changes in environmental (external and colony) conditions. Colony age structure is one aspect of the environment that changes throughout the year owing to changing individual birth and death rates [reviewed by Moritz and Southwick (1992)]. For example, a colony of honey bees in early spring is composed mostly of old bees that lived through the winter. At this time older bees must handle the tasks normally performed by younger individuals. After they die a few weeks later, there are very few older bees available to forage but an expanding population of younger individuals that now must take on an unusually broad range of duties, including precocious foraging. Other factors that can alter the age demography of a colony include reproductive colony fission (Robinson et al., 1989), predation on foragers and brood diseases.

Honey bees are able to respond to changing colony needs by altering their typical patterns of age polyethism, another example of the high level coordination among colony members that exists in honey bee colonies in the absence of centralized control (Wilson and Hölldobler, 1988; Seeley, 1995). This paper reviews our understanding of the mechanisms that enable honey bees to show plasticity in age polyethism in response to changing conditions. We focus on one aspect of age polyethism, the age at onset of foraging.
The transition from hive tasks to foraging is the most striking and best understood aspect of honey bee age polyethism.

\section{GENETIC AND ENDOCRINE INFLUENCES ON DIVISION OF LABOR}

It is now well-established that genetic variation among worker honey bees influences the division of labor in several different ways [reviewed by Page and Robinson (1991), Robinson (1992) and Moritz and Southwick (1992)]. There is genetic variation for plasticity in age polyethism. Due to multiple mating by the queen, a colony of honey bees is composed of different subfamilies [reviewed by Page (1986)]. In a 'single-cohort' colony, an experimental unit initially composed of $1500-2000$ newly eclosed bees, workers of some subfamilies are more likely to become precocious foragers than are workers of other subfamilies (Robinson et al., 1989; Page et al., 1992). As this colony ages, workers of other subfamilies are more likely to continue as overage nurses, i.e. to care for the brood despite advancing chronological age (Robinson et al., 1989).

Giray and Robinson (1994) demonstrated that genetic variation for plasticity in age polyethism is not based on genetic variation for sensitivity to changing colony conditions. Rather, genotypes that have relatively fast rates of behavioral development under more typical conditions are more inclined to show precocious foraging in the absence of normal age foragers. Similarly, genotypes that have relatively slow rates of behavioral development under typical conditions are inclined towards overage nursing in the absence of normal age nurses. There are other reports of genotypic differences in rates of honey bee behavioral development (Winston and Katz, 1982; Calderone 
and Page, 1988; Kolmes et al., 1989). These results indicate that age polyethism and its plasticity are under similar control mechanisms.

One molecule that is involved in the control of both age polyethism and plasticity in age polyethism is juvenile hormone (JH) [reviewed by Fahrbach (1997), Fahrbach and Robinson (1996) and Robinson and Vargo (1997)]. Hemolymph titers of JH increase with age (Rutz et al., 1976; Huang et al., 1991, 1994), and treatment with JH (Jaycox, 1976), JH mimic (Jaycox et al., 1974), and JH analog (e.g. Robinson, 1987a, b; Sasagawa et al., 1989) induces precocious foraging. Recently it has been shown that removal of the corpora allata (the glands that produce $\mathrm{JH}$ ) delays, but does not prevent, bees from developing into foragers; the delay is eliminated with $\mathrm{JH}$ analog treatment (Sullivan et al., 1996). These results indicate that JH influences how fast a bee grows up and makes the transition from nest activities to foraging. It is assumed that this occurs by the effects of JH on the central nervous system (Robinson, 1987b; Withers et al., 1995), but conclusive evidence for this is lacking. Progress in determining the relationship between $\mathrm{JH}$ and the central nervous system of insects in general has been hampered by a poor understanding of $\mathrm{JH}$ receptors in any insect species, in any tissue (Fahrbach and Robinson, 1996).

In vertebrates, it is well-known that some hormones coordinate physiological and behavioral development. JH plays such a role in honey bee division of labor, allowing changes in the activity of some exocrine glands that are associated with age polyethism to proceed in step with behavioral transitions. For example, when bees are young and in the nursing phase of life, their hypopharyngeal glands are largest and produce major components of larval food; these glands become atrophied in foragers and shift to produce $\alpha$-glucosidase, an enzyme involved in the con- version of nectar into honey (Winston, 1987). Low titers of $\mathrm{JH}$ or rates of $\mathrm{JH}$ biosynthesis are typically associated with well-developed hypopharyngeal glands, while $\mathrm{JH}$ treatment induces premature hypopharyngeal gland degeneration (Rutz et al., 1974; Beetsma and Ten Houten, 1974; Jaycox et al., 1974; Jaycox, 1976; Sasagawa et al., 1989; Huang et al., 1994). Methoprene treatment similarly induces premature production of the alarm pheromones 2-heptanone and iso-amyl acetate (Robinson, 1985). In contrast, JH apparently does not influence the timing of wax gland development or comb building behavior in Apis mellifera capensis (Muller and Hepburn, 1994). The reason for this difference may be because comb building behavior occurs over a relatively broad range of worker ages, at least under the experimental conditions of Muller and Hepburn (1994) [for other possible explanations see Robinson and Vargo (1997)].

Hormones also are well-known as 'environmental transducers', in both invertebrates and vertebrates (e.g. Nijhout, 1994). Environmentally induced changes in age polyethism apparently occur, at least in part, by affecting the JH system. For example, in single cohort colonies precocious foragers have forager-like (high) JH titers (Robinson et al., 1989; Huang and Robinson, 1992) and overage nurses have nurse-like (low) JH titers (Robinson et al., 1989). Overage nurses also occur naturally when a swarm of honey bees establishes a new colony. Although a swarm is composed of bees of all ages, it develops an age structure dominated by older individuals because new adults do not emerge until 3 weeks after the first eggs are laid. Overage nurses in newly founded colonies have low JH titers (Robinson et al., 1989). Behavioral reversion, from foraging to nursing, may occur if there are no other nurses in the colony (Page et al., 1992; Robinson et al., 1992, and references therein), and reverted 
nurses show correspondingly lower $\mathrm{JH}$ titers (Robinson et al., 1992; Huang and Robinson, 1996). Similarly, there is a drop in $\mathrm{JH}$ titers and rates of biosynthesis in the fall as foraging diminishes and bees become less active (Huang and Robinson, 1995). This natural drop in JH confirms and extends findings of experimentally induced reversion. These results suggest that perception of certain environmental conditions leads to changes in $\mathrm{JH}$ titers that result, directly or indirectly, in altered age polyethism. As discussed above, these changes are more likely to occur in bees belonging to certain subfamilies owing to genotypic differences in rate of behavioral development. Studies examining genotypic differences in the honey bee JH system are currently underway. The results reviewed here outline the genetic and endocrine bases of a decentralized mechanism of social integration that enables workers to respond to fragmentary information with actions that are appropriate to the state of the whole colony.

\section{COLONY AGE DEMOGRAPHY, SOCIAL INTERACTIONS AND THE CONTROL OF DIVISION OF LABOR}

One environmental factor, colony age demography, plays a key role in the control of honey bee age polyethism (Huang and Robinson, 1992, 1996). There is a strong negative relationship between the amount of old bees in a colony and the proportion of precocious foragers: the more old bees present, the fewer the precocious foragers (Huang and Robinson, 1996). In a single-cohort colony of young bees, about $5-10 \%$ of the individuals show precocious behavioral development and begin foraging when they are 6-10 days old. But transplanting a group of normal age foragers into such a colony inhibits precocious foraging. Similar results were obtained from colonies with more typical age structures (Huang and Robinson, 1996). When a portion of a colony's foragers is removed to simulate predation, young bees develop faster compared to those in a control colony in which the same number of bees are depleted, but evenly across the different age classes. Conversely, when foragers are confined to their hive by artificial rain, young bees delay, rather than accelerate, their development.

Does colony age demography influence the division of labor directly or indirectly? For example, is it the lack of foragers that leads to precocious behavioral development by some bees or changes in the hive environment caused by a lack of foragers, such as a decrease in food stores or no fresh nectar or pollen? The evidence to date, reviewed in the next paragraph, points decisively towards a direct effect of colony age demography.

Huang and Robinson (1992) showed that not only does a transplant of foragers into a single-cohort colony inhibit precocious foraging, but the inhibition persists even if the transplanted foragers are themselves not allowed to forage. This means that the young resident bees are likely to be inhibited by the foragers directly, rather than stimulated to forage by some change in the hive environment such as a decrease in food stores or a lack of freshly collected food. A similar conclusion can be drawn from experiments in which foragers are confined by artificial rain. In this case there is a delay in behavioral development even though again it is expected that forager confinement led to a decrease in food stores or a lack of freshly collected food (Huang and Robinson, 1996). These results are consistent with those obtained in laboratory studies in which 1-day-old bees are reared for 7 days either in complete social isolation, in small groups, or in typical colonies (Huang and Robinson, 1992). Bees reared in small groups show normal, nurse-like rates of $\mathrm{JH}$ biosynthe- 
sis, demonstrating that a normal hive environment is not necessary for normal agerelated changes in $\mathrm{JH}$. In contrast, bees that lack social contact have precociously high rates of $\mathrm{JH}$ biosynthesis, and are more likely to become precocious foragers than bees from the other two groups.

Recent results by Schulz et al. (1998) further demonstrate that bees do not become precocious foragers in response to a perception of a decrease in carbohydrate food stores. Schulz et al. (1998) first showed that food shortage induces an acceleration of behavioral development in single-cohort colonies; a greater proportion of bees from starved colonies become precocious foragers relative to fed colonies, and at younger ages. They then conducted further experiments in which bees were allowed to feed freely on sugar syrup but were not allowed to store any of it in their comb. This was accomplished by drilling holes in every cell of a (onesided) comb and continually removing (by vacuum) any stored food. The behavioral development of fed individuals in starved single-cohort colonies was indistinguishable from that of bees in fed colonies, but markedly different than bees in starved colonies, both in terms of the number and age distribution of foragers. These results demonstrate that effects of starvation on age polyethism are not mediated by an assessment of colony food stores. Either starvation induced differences in social interactions or direct effects of starvation on individual bees are exerting an influence on age polyethism in honey bee colonies.

Huang and Robinson (1992) presented a descriptive model to explain how colony age demography and social interactions can influence age-related division of labor in honey bee colonies. JH was originally described in this model as an 'activator' that promotes behavioral development; in light of the above-mentioned findings for allatectomized bees (Sullivan et al., 1996), it now is more appropriate to specify that JH influences rate of behavioral development. The model also invokes an 'inhibitor', transferred by workers, that suppresses JH and behavioral development. The activator and inhibitor are hypothesized to be coupled, such that older bees, with high JH titers, either produce or transfer more inhibitor than do younger workers. This social inhibition can be mediated by behavior, chemicals, or both. Preliminary efforts at computer simulation of the activator-inhibitor model suggest that it can result in nurse bees with low JH titers, foragers with high $\mathrm{JH}$ titers, and an intermediate group under a variety of demographic conditions (Z.-Y. Huang et al., unpublished results).

One difference between this model and other activator-inhibitor models in biology (e.g. Turing, 1952; MacWilliams, 1983 ) is that the activator is hypothesized to work only 'within' individual bees; it is not spread 'among' individuals. In contrast, the inhibitor is assumed to be spread among individuals. The activator and inhibitor in this model thus do not work at the same level of organization, while in other activator-inhibitor models they do (Meinhardt, 1993).

No specific worker inhibitor has been identified, but it is clear that social inhibition of age polyethism requires physical contact. We (Huang et al., in press) reared 1-day-old bees for 7 days in a typical colony in one of three ways: individually in cages with double screens that prevented physical contact with colony members, individually in cages with single screens that allowed only antennation and food exchange with colony members, or with unrestricted access to colony members (control bees). Bees reared in double-screen cages always have precociously high $\mathrm{JH}$ hemolymph titers and rates of $\mathrm{JH}$ biosynthesis and were more likely to become precocious foragers than bees from the other two groups. These results 
demonstrate that physical contact is required for inhibition.

In the same study, bees reared in singlescreen cages only sometimes had higher JH than control bees; sometimes they did not. Moreover, although a greater proportion of bees reared in single-screen cages showed precocious foraging relative to control bees, the proportion was less than for bees reared in double-screen cages. These results indicate that bees that are physically separated from older individuals by a single, rather than double, screen are only partially inhibited. They implicate food transfer, antennal contact, licking, or some combination of these in the social inhibition process because they were the only type of interactions possible between a bee in a single-screen cage and uncaged colony members.

\section{CHEMICAL COMMUNICATION AND THE CONTROL OF DIVISION OF LABOR}

Chemical communication is extensive in honey bee colonies (Winston, 1987; Free, 1987; Robinson, 1996). Chemical cues mediate many different activities, including care of the brood (Free and Winder, 1983; Huang et al., 1989; Le Conte et al., 1990) and queen (Winston and Slessor, 1992), nestmate recognition (Breed et al., 1994), foraging (Winston, 1987), and nest defense (Collins et al., 1980). Given that food transfer, antennal contact, licking, or some combination of these are apparently involved in governing rate of behavioral development, it is reasonable to hypothesize that the strong effects of colony age demography on division of labor also are mediated, at least in part, by chemical communication.

One pheromone that recently has been shown to be involved in the control of age polyethism is queen mandibular pheromone (QMP), a five-component pheromone produced by the mandibular glands of the queen (Pankiw et al., 1998). QMP is composed of the fatty acids 9keto- $(E) 2$-decenoic acid (9-0DA), $R$-9hydroxy-(E)2-decenoic acid ( $R$-9-HDA), and $S$-9-HDA, and two aromatics, methyl p-hydroxybenzoate and 4-hydroxy-3methoxyphenylethanol [reviewed by Winston and Slessor (1992)]. This pheromone has been known for some time to exert long-lasting primer effects on physiology and behavior by inhibiting the rearing of new queens by workers. It also exerts releaser effects, causing workers to perform retinue behavior in which they feed, groom, and touch the queen with their antennae, resulting in the transfer of pheromone from the queen to workers (Naumann et al., 1991). Kaatz et al. (1992) showed that QMP inhibits the rate of worker JH biosynthesis. Moreover, bees from colonies treated with supplemental doses of QMP had lower JH titers and began to forage at older ages than bees from control colonies (Pankiw et al., 1998). These results show that honey bee age polyethism is influenced by QMP.

Results with QMP demonstrate that age polyethism can be influenced by chemical communication. But we believe that the primary modulator of worker behavioral development is a signal or signals that emanate from the workers themselves. This is because it is possible to drastically alter age polyethism by altering colony worker age demography, while maintaining constant the presence of the queen (Huang and Robinson, 1992, 1996; Giray and Robinson, 1994). Furthermore, there is no evidence that pheromone production or transmission by queens varies except as a function of colony density (Winston and Slessor, 1992). It is therefore likely that QMP functions as an auxiliary inhibitor to fine-tune the division of labor in response to changing colony needs. Since workers contact the queen most frequently as nurse bees (Seeley, 
1982), this exposure would serve to prolong their nursing phase, perhaps better matching the size of the nurse force to the number of larvae that need to be cared for.

QMP effects on age polyethism also led to the hypothesis that worker mandibular glands contain an inhibitor of behavioral development. The mandibular glands of workers contain compounds similar to those found in queen mandibular glands, including the predominant worker mandibular acid, 10-hydroxy(E)2-decenoic acid (10-HDA) (Plettner et al., 1996). Because QMP is exchanged during food exchange or antennal contact (Naumann et al., 1991), perhaps the contents of the worker mandibular glands are also; this is relevant because there must be direct social contact between bees for inhibition to occur (Huang et al., in press). We have begun to test the hypothesis that worker mandibular glands contain an inhibitor of behavioral development by determining whether older bees with their mandibular glands removed are just as inhibitory towards younger bees as are intact individuals (Huang et al., in press). They are not; when older bees with their mandibular glands removed are transplanted into a single-cohort colony, they did not inhibit precocious foraging as effectively as did intact or sham-operated older bees. These results are consistent with the hypothesis that worker mandibular glands contain an inhibitor of behavioral development. But it is possible that removal of the mandibular glands affects behavior or the transmission of chemical signals produced elsewhere. Experiments that seek to determine whether extracts of the mandibular glands of older workers are inhibitory to younger bees are in progress.

\section{CONCLUSIONS}

Conclusive identification of the hypothesized worker inhibitor is necessary to demonstrate the validity of the activator-inhibitor model for honey bee behavioral development. This information will also open new lines of study on precisely how age demography and social interactions control age polyethism in the face of ever-changing conditions. At present, we cannot rule out the possibility that colony age demography acts via social mechanisms other than the one specified by the activator-inhibitor model. In addition, even if the activator-inhibitor model is further validated, it is likely that other inhibitors and activators are involved. Queen mandibular pheromone already has been shown to act as an inhibitor of $\mathrm{JH}$ and behavioral development, and there are probably others that await discovery. Activation of behavioral development by factors other than $\mathbf{J H}$ also is likely (Sullivan et al., 1996). Mechanosensory activation of behavioral development via the "tremble dance' is suggested by the results of Seeley et al. (1996). It also is important to study the performance of other tasks in the honey bee age polyethism schedule in the context of the activator-inhibitor model. The activator-inhibitor model will undoubtedly be revised in the future, but at present it provides a heuristic tool to understand the roles of genetics, physiology, colony age demography and labor needs in the control of division of labor.

The details of the activator-inhibitor model remain to be experimentally demonstrated. But it is clear that changes in the age at onset of foraging are influenced by changes in colony age demography, which in turn are at least partially a consequence of social interactions in which older bees inhibit the rate of behavioral development of younger bees. These conclusions parallel those by Seeley (1995) for the regulation of nectar foraging. Seeley concludes 
from his studies that one prominent element of colony organization is that individual bees largely gain information about the needs of their colony via cues that are obtained during interactions with other colony members, rather than by assessing colony needs directly during independent inspections of the hive itself. Colony behavioral integration via social interactions is emerging as a prominent theme in the organization of insect societies (Robinson, 1992; Seeley, 1995; Gordon, 1996). But it is premature to eliminate the possibility that some forms of worker-nest interactions related to task needs also play a role in the control of age polyethism and other aspects of division of labor.

One frontier in studies of colony-level regulation of worker behavior is to determine the relative contributions of mechanisms based on worker-worker and worker-nest interactions. This knowledge will help direct efforts towards further elucidating underlying endocrine, neural (e.g. Withers et al., 1993), and genetic mechanisms regulating social insect behavior. It is hoped that the studies reviewed here will contribute towards the goal of developing a socioneuroethological understanding of colony behavioral integration which spans organizational levels, from the colony to the gene.

\section{ACKNOWLEDGMENTS}

We thank Y. Ben-Shahar, S.L. Beshers and D.J. Schulz and two anonymous reviewers for comments that improved this manuscript. Research from this laboratory was supported by grants from the National Institutes of Health, National Science Foundation (to GER and Susan E. Fahrbach) and the United States Department of Agriculture.

Résumé - Intégration de la colonie chez Apis mellifera L. : régulation génétique, endocrine et sociale de la division du travail. Cet article rassemble nos connaissances concernant les mécanismes qui permettent aux abeilles ouvrières adultes de faire preuve de plasticité dans le polyéthisme lié à l'âge en réponse aux conditions variables du milieu. Il existe des différences génotypiques dans la vitesse de développement comportemental qui prédisposent les individus à répondre aux conditions variables selon des modalités qui peuvent être prédites. Par exemple, les génotypes qui présentent une vitesse de développement comportemental relativement rapide dans des conditions typiques ont une tendance plus marquée à butiner précocement dès que les butineuses d'âge normal manquent. L'hormone juvénile $(\mathrm{HJ})$ joue un rôle important dans la régulation du polyéthisme lié à l'âge. L'un de ses rôles consiste à coordonner les changements de comportement avec les changements de l'activité des glandes exocrines associées au polyéthisme lié à l'âge. Un résultat récent, qui devrait conduire à une meilleure compréhension du rôle de l'HJ dans le polyéthisme lié à l'âge, a montré que l'ablation des corpora allata retarde, mais n'empêche pas, les abeilles de devenir butineuses ; ce retard est annulé par un traitement à l'HJ. Parce que les variations de niveau d'HJ en réponse aux conditions variables de la colonie concordent avec les réponses comportementales, on pense que les changements de teneur en HJ induits par l'environnement sont à la base des changements du polyéthisme lié à l'âge. Les résultats d'expériences récentes montrent que les changements dans le début du butinage se produisent en réponse directe aux changements de la pyramide des âges de la colonie. Ces derniers sont communiqués au sein de la colonie par les interactions sociales par lesquelles les abeilles les plus vieilles inhibent la vitesse de développement comportemental des plus jeunes. Cette affirmation est confirmée par le fait que des butineuses transferrées dans une colonie composée uniquement de jeunes abeilles inhibent le 
butinage précoce et cette inhibition persiste même si l'on empêche les butineuses transferrées de butiner. Cela signifie que les jeunes abeilles résidentes sont vraisemblablement inhibées directement par les butineuses, plutôt que stimulées à butiner par quelque changement dans l'environnement de la ruche, tel qu'une diminution des réserves ou un manque de nourriture fraîchement récoltée. D'autres résultats qui concordent avec cette interprétation sont présentés. Des signaux chimiques sont soupçonnés d'agir principalement dans les interactions sociales qui influencent le développement comportemental. Un traitement supplémenté en phéromone de la glande mandibulaire de la reine (QMP) inhibe les teneurs en $\mathrm{HJ}$ et retarde le début du butinage. De plus, les abeilles les plus vieilles, desquelles ont été extraites les glandes mandibulaires, ne sont pas aussi inhibitrices vis-à-vis des plus jeunes que des abeilles intactes ; lorsque les abeilles les plus vieilles privées de leurs glandes mandibulaires sont transferrées dans une colonie composée d'une seule classe d'âge, elles n'inhibent pas le butinage précoce aussi efficacement que le font des abeilles plus vieilles intactes ou des pseudo-opérées. Ces résultats sont cohérents avec l'hypothèse selon laquelle les glandes mandibulaires des ouvrières renferment un inhibiteur du développement comportemental, mais l'ablation des glandes mandibulaires peut influer sur le comportement ou la transmission des signaux chimiques produits ailleurs. Des expériences sont en cours qui cherchent à déterminer si des extraits de glandes mandibulaires d'ouvrières âgées inhibent les ouvrières plus jeunes. On espère que les études mentionnées ici contribueront à développer une compréhension socioneuroéthologique de l'intégration comportementale de la colonie, intégration qui couvre les niveaux organisationnels de la colonie au gène. (C) Inra/DIB/AGIB/Elsevier, Paris

\section{Apis mellifera / génétique comportement / hormone juvénile / communication chimique}

\section{Zusammenfassung - Integration des Bienenvolkes (Apis mellifera): Geneti- sche, endokrine und soziale Steuerung} der Arbeitsteilung. In diesem Artikel wird unser Verständnis der Mechanismen dargestellt, die adulte Arbeiterinnen der Honigbienen (Apis mellifera) dazu befähigen, ihre altersabhängige Arbeitsteilung plastisch an wechselnde Umgebungsbedingungen anzupassen. Hier spielen genetische Unterschiede in der Geschwindigkeit der individuellen Entwicklung eine Rolle und führen zu vorhersagbaren Reaktionen auf einen Wechsel der Umgebungsbedingungen. Beispielsweise zeigen Genotypen mit einer unter typischen Bedingungen relativ schnellen Entwicklung ihres Verhaltens eine höhere $\mathrm{Nei}$ gung zu vorzeitigem Sammelverhalten, sobald Sammlerinnen normalen Alters fehlen. Juvenilhormon (JH) spielt bei der Steuerung der altersabhängigen Arbeitsteilung eine wichtige Rolle. Zum einen koordiniert es die Wechsel im Verhalten mit den Änderungen der Aktivität exokriner Drüsen, die mit der altersabhängigen Arbeitsteilung im Zusammenhang stehen. Weiter beeinflußt es, in welchem Alter das Sammelverhalten einsetzt. Ein neuer, für das Verständnis von $\mathrm{JH}$ in der alterabhängigen Arbeitsteilung wegweisender Befund ist, daß die Entfernung der Corpora allata den Übergang zum Sammelverhalten verzögert, aber nicht verhindert; diese Verzögerung kann durch Behandlung mit JH-Analogen aufgehoben werden. Da die Änderungen der JH-Spiegel bei wechselnden Zuständen des Bienenvolks mit den Verhaltensreaktionen übereinstimmen, stellen wir uns vor, daß von der Umgebung hervorgerufene Änderungen des JH-Titers der altersabhängigen Arbeitsteilung zugrunde liegen. Neue Experimente weisen darauf hin, daß Ände- 
rungen des Alters beim Einsetzen der Sammelflüge eine direkte Folge von Änderungen der Zusammensetzung des Bienenvolkes sind. Änderungen der Altersdemographie werden im Bienenvolk über soziale Interaktionen kommuniziert, bei denen die älteren Bienen die Geschwindigkeit der Verhaltensentwicklung der jüngeren Bienen verlangsamen. Diese Behauptung wird durch folgende Verknüpfung von Befunden gestützt: Die Entwicklung vorzeitigen Sammelns in Völkern aus altersgleichen jungen Arbeiterinnen wird durch das Zusetzen von Sammlerinnen gehemmt. Diese Hemmung erfolgt sogar dann, wenn die zugesetzten Sammlerinnen am Sammeln gehindert werden. Dies bedeutet eher, daß die jungen Bienen wahrscheinlich direkt von den zugesetzten Sammlerinnen gehemmt werden, als daß sie durch Änderungen der Umgebung im Volk wie der Verringerung der Futtervorräte oder von frischgesammeltem Futter stimuliert werden. Weitere Untersuchungen passen mit diesen Ergebnissen zusammen. Chemische Signale stehen im Verdacht, besonders bei den sozialen Interaktionen wirksam zu sein, die die Entwicklung des Verhaltens beeinflussen. Die Behandlung mit zusätzlichem Mandibeldrüsensekret der Königin hemmt den JH-Titer und verzögert den Beginn des Sammelns. Darüber hinaus ist die hemmende Wirkung älterer Bienen nach Entfernung der Mandibeldrüsen verringert. Das Zusetzen älterer Arbeiterinnen mit entfernten Mandibeldrüsen in Völker aus altersgleichen Arbeiterinnen verhinderte das vorzeitige Sammeln nicht so effektiv wie das Zusetzen von nicht oder zum Schein operierten älteren Arbeiterinnen. Diese Ergebnisse stimmen mit der Hypothese überein, daß die Mandibeldrüsen der Arbeiterinnen einen Inhibitor der Verhaltensentwicklung enthalten. Allerdings könnte die Entfernung der Drüsen auch das Verhalten oder die Übertragung von an anderen Stellen erzeugten chemischen Signalen beeinflußt haben. Zur Zeit werden
Experimente zur Klärung der Frage durchgeführt, ob die Verhaltensentwicklung junger Bienen durch Mandibeldrüsenextrakte älterer Bienen gehemmt werden kann. Wir hoffen, daß die hier dargestellten Untersuchungen einen Beitrag zur Erreichung des Ziels eines sozioneuroethologischen Verständnisses der Verhaltensintegration in den Völkern darstellen, welches die verschiedenen Organisationsebenen, letztendlich von der Kolonie bis zum Gen umfasst. (c) Inra/DIB/AGIB/Elsevier, Paris

\section{Apis mellifera / Verhaltensgenetik / Juvenilhormon / chemische Kommuni- kation}

\section{REFERENCES}

Breed MD, Welch CK, Cruz R (1994) Kin discrimination within honey bee (Apis mellifera) colonies: an analysis of evidence. Behav Proc $33,25-40$

Beetsma J, Ten Houten A (1974) Effects of juvenile hormone analogues in the food of honeybee colonies. Z Angew Entomol 77, 292-300

Calderone NW, Page RE Jr (1988) Genotypic variability in age polyethism and task specialization in the honey bee, Apis mellifera (Hymenoptera: Apidae). Behav Ecol Sociobiol 22, 17-25

Collins AM, Rinderer TE, Tucker KW, Sylvester HA, Lackett JJ (1980) A model of honeybee defensive behaviour. J Apic Res 19, 224-231

Fahrbach SE (1997) Regulation of age polyethism in bees and wasps by juvenile hormone. Adv Study Behav 26, 285-316

Fahrbach SE, Robinson GE (1996) Juvenile hormone, behavioral maturation, and brain structure in the honey bec. Dev Neurosci 18, 102-114

Free JB (1987) Pheromones of Social Bees. Cornell Univ Press, Ithaca, NY

Free JB, Winder ME (1983) Brood recognition by honey bee (Apis mellifera) workers. Anim Behav 31, 539-545

Giray T, Robinson GE (1994) Effects of intracolony variability in behavioral development on plasticity of division of labor in honey bee colonies. Behav Ecol Sociobiol 35, 13-20

Gordon DM (1996) The organization of work in insect colonies. Nature 380, 121-124

Hölldobler B, Wilson EO (1990) The Ants. Belknap Press, Cambridge, MA 
Huang Z-Y, Robinson GE (1992) Honeybee colony integration: worker-worker interactions mediate hormonally regulated plasticity in division of labor. Proc Natl Acad Sci USA 89, 11726-11729

Huang Z-Y, Robinson GE (1995) Seasonal changes in juvenile hormone titers and rates of biosynthesis in honey bees. J Comp Physiol B 165 , $18-28$

Huang Z-Y, Robinson GE (1996) Regulation of honey bee division of labor by colony age demography. Behav Ecol Sociobiol 39, 147-158

Huang Z-Y, Otis GW, Teal PEA (1989) Nature of brood signal activating the protein synthesis of hypopharyngeal glands in the honey bee, Apis mellifera (Apidae: Hymenoptera). Apidologie $20,455-464$

Huang Z-Y, Robinson GE, Borst, DW (1994) Physiological correlates of division of labor among similarly aged honey bees. J Comp Physiol A $174,731-739$

Huang Z-Y, Robinson GE, Tobe SS, Yagi KJ Strambi C, Strambi A, Stay B (1991) Hormonal regulation of behavioural development in the honey bee is based on changes in the rate of juvenile hormone biosynthesis. J Insect Physiol 37, $733-741$

Huang Z-Y, Plettner E, Robinson GE (1998) Effects of social environment and worker mandibular glands on endocrine-mediated behavioral development in honey bees. $J$ Comp Physiol A, in press

Jaycox ER (1976) Behavioral changes in worker honey bees (Apis mellifera L.) after injection with synthetic juvenile hormone (Hymenoptera: Apidae). J Kans Entomol Soc 49, 165-170

Jaycox ER, Skowronek W, Gwynn G (1974) Behavioral changes in worker honey bees (Apis mellifera) induced by injections of a juvenile hormone mimic. Ann Entomol Soc Am 67, 529-534

Kaatz H-H, Hildebrandt H, Engels W (1992) Primer effect of queen pheromone on juvenile hormone biosynthesis in adult worker honey bees. I Comp Physiol B 162, 588-592

Kolmes SA, Winston ML, Fergusson LA (1989) The division of labor among worker honey bees (Hymenoptera: Apidae): the effects of multiple patrilines. I Kans Entomol Soc, 62, 80-95

Le Conte Y, Arnold G, Trouiller J, Masson C (1990) Identification of a brood pheromone in honeybees. Naturwissenschaften 77, 334-336

MacWilliams, HK (1983) Hydra transplantation phenomena and the mechanism of hydra head regeneration. II. Properties of the head activation. $\mathrm{Dev}$ Biol 96, 239-257

Meinhardt, H (1993) A model for pattern formation of hypostome, tentacles, and foot in Hydra: how to form structures close to each other, how to form them at a distance. Dev Biol 157, 321-333
Moritz RFA, Southwick EE (1992) Bees as Superorganisms: An Evolutionary Reality. SpringerVerlag, Berlin

Muller WJ, Hepburn HR (1994) Juvenile hormone III and wax secretion in honey bees (Apis mellifera capensis).J Insect Physiol 40, 873-881

Naumann K, Winston ML, Slessor KN, Prestwich, GD, Webster FX (1991) Production and transmission of honey bee queen (Apis mellifera $\mathrm{L}$.) mandibular pheromone. Behav Ecol Socibiol 29, $321-332$

Nijhout HF (1994) Insect Hormones. Princeton Univ Press, Princeton

Page, RE Jr (1986) Sperm utilization in social insects. Annu Rev Entomol 31, 297-320

Page, RE, Jr, Robinson G.E. (1991) The genetics of division of labour in honey bee colonies. $A d v$ Insect Physiol 23, 117-171

Page RE, Jr, Robinson GE, Britton DS, Fondrk MK (1992) Genotypic variability for rates of behavioral development in worker honeybees (Apis mellifera L.). Behav Ecol 3, 173-180

Pankiw T, Huang Z-Y, Winston ML, Robinson GE (1998) Queen mandibular gland pheromone influences worker honey bee (Apis mellifera $\mathbf{L}$.) foraging ontogeny and juvenile hormone titers. $J$ Insect Physiol (in press)

Plettner E, Slessor KN, Winston ML, Oliver JE (1996) Caste-selective pheromone biosynthesis in honeybees. Science 271, 1851-1853

Robinson GE (1985) Effects of a juvenile hormone analogue on honey bee foraging behaviour and alarm pheromone production. I Insect Physiol $31,277-282$

Robinson GE (1987a) Regulation of honey bee age polyethism by juvenile hormone. Behav Ecol Sociobiol 20, 329-338

Robinson GE (1987b) Modulation of alarm pheromone perception in the honey bee: evidence of division of labor based on hormonally regulated response thresholds. J Comp Physiol A 160 , 613-619

Robinson GE (1992) Regulation of division of labor in insect societies. Annu Rev Entomol 37, $637-665$

Robinson GE (1996) Chemical communication in honeybees. Science 271, 1824-1825

Robinson GE, Vargo EI (1997) Juvenile hormone in adult eusocial Hymenoptera: gonadotropin and behavioral pacemaker. Arch Insect Biochem and Physiol 35, 559-583

Robinson GE, Page RE, Jr, Strambi C, Strambi A (1989) Hormonal and genetic control of behavioral integration in honey bee colonies. Science $246,109-112$

Robinson GE, Page RE, Strambi C, Strambi A (1992) Colony integration in honey bees: mechanisms of behavioural reversion. Ethology 90, 336-350 
Rutz W, Gerig L, Wille H, Lüscher M (1974) A bioassay for juvenile hormone $(\mathrm{JH})$ effects of insect growth regulators (IGR) on adult worker honeybees. Mitt Schweiz Entomol Ges 47, 307-313

Rutz W, Gerig L, Wille H, Lüscher M (1976) The function of juvenile hormone in adult worker honeybees, Apis mellifera. J Insect Physiol 22, 1485-1491

Sasagawa H, Sasaki M, Okada I (1989) Hormonal control of the division of labor in adult honeybees (Apis mellifera L.). I. Effect of methoprene on corpora allata and hypopharyngeal gland, and its alpha-glucosidase activity. Appl Entomol Zool 24, 66-77

Schulz, DJ, Huang, Z-Y, Robinson GE. (1998) Effects of colony food shortage on behavioral development in honey bees. Behav Ecol Sociobiol (in press)

Seeley TD (1982) Adaptive significance of the age polyethism schedule in toneybee colonies. Behav Ecol Sociobiol 11, 287-293

Seeley TD (1995) The Wisdom of the Hive. The Social Physiology of Honey Bee Colonies. Harvard Univ Press, Cambridge

Seeley TD, Kühnholz, S, Weidenmüller A (1996) The honey bee's tremble dance stimulates addi- tional bees to function as nectar receivers. Behav Ecol Sociobiol 39, 419-427

Sullivan, JP, Jassim O, Robinson GE, Fahrbach SE (1996) Foraging behavior and mushroom bodies in allatectomized honey bees. Soc Neuro Abst 22,1144

Turing, AM (1952) The chemical basis of morphogenesis. Phil Trans Roy Soc B 237, 5-72

Wilson EO, Hölldobler B (1988) Dense heterarchies and mass communication as the basis of organization in ant colonies. Trends Ecol Evol 3, 65-68

Winston ML (1987) The Biology of the Honey Bee. Harvard Univ Press, Cambridge

Winston ML, Katz SJ (1982) Foraging differences between cross-fostered honeybee workers (Apis mellifera) of European and Africanized races. Behav Ecol Sociobiol 10, 125-9

Winston ML, Slessor KN (1992) The essence of royalty: honey bee queen pheromone. Am Sci 80 . 374-385

Withers GS, Fahrbach SE, Robinson GE (1993) Selective neuroanatomical plasticity and division of labour in the honeybee. Nature 364 , 238-240

Withers GS, Fahrbach, SE, Robinson GE (1995) Effects of experience and juvenile hormone on the organization of the mushroom bodies of the honey bees. $J$ Neurobiol 26, 130-144 